\title{
Plasma concentrations of 15-keto-13,14-dihydro-PGF-2 $\alpha$, oestrone sulphate, oestradiol-17 $\beta$ and progesterone in pregnant guinea-pigs treated with polychlorinated biphenyls
}

\author{
U. Lundkvist and H. Kindahl* \\ Department of Zoophysiology, Uppsala University, Box 560, S-751 22 Uppsala, Sweden; and \\ *Department of Obstetrics \& Gynaecology, Swedish University of Agricultural Sciences, \\ S-750 07 Uppsala, Sweden
}

\begin{abstract}
Summary. Guinea-pigs treated by gavage with a total dose of $100 \mathrm{mg}$ polychlorinated biphenyls (PCB: Clophen A50) during Days 17-61 of gestation had higher plasma concentrations of 15-keto-13,14-dihydroprostaglandin F-2 $\alpha$, oestrone sulphate and oestradiol-17 $\beta$ during the later stages of gestation than did vehicle-treated guinea-pigs. No changes were observed in plasma progesterone concentrations. Our results provide no support for the hypothesis that an enzyme-induced decrease in progesterone concentrations is the main cause of the fetal death observed in PCB-treated guinea-pigs.
\end{abstract}

Keywords: plasma hormones; guinea-pig; PCB; fetal death

\section{Introduction}

The polychlorinated biphenyls (PCBs) comprise a group of environmental contaminants (Jensen, 1966) that are persistent in biological systems. PCBs have had many industrial uses because of their physical and chemical properties, such as thermal stability, a high dielectric constant and low volatility (Hutzinger et al., 1974). Numerous toxic effects have been reported in experimental animals and in humans accidentally exposed to PCBs (for review see Higuchi, 1976; Safe, 1984; Fuller \& Hobson, 1986). Effects on the reproductive system include abortion, resorptions or stillbirths, and reduced survival of young in rats (Linder et al., 1974; Brezner et al., 1984), rhesus monkeys (Barsotti et al., 1976; McNulty, 1985), mink (Aulerich et al., 1985), rabbits (Villeneuve et al., 1971) and guinea-pigs (Brunström et al., 1982), prolonged oestrous cycles and precocious vaginal opening in rats (Brezner et al., 1984), and prolonged menstrual cycles with excessive and lengthy menstrual bleeding in monkeys (Barsotti et al., 1976).

Owing to their fat solubility, PCBs and/or their metabolites are accumulated in fat tissue (Jensen \& Sundström, 1974; Sparling \& Safe, 1980). Hydroxylated and methylsulphonated metabolites of PCB have also been identified in fetuses (Darnerud et al., 1986) and in uterine luminal fluid (Brandt et al., 1982). It is not known whether placental transfer of PCBs is a prerequisite for fetal death. Available data suggest that the magnitude of exposure in utero via transplacental transfer of PCBs (Masuda et al., 1978, 1979; Ring et al., 1988) is small compared to exposure via suckling (Vodicnik \& Leech, 1980; Shain et al., 1986). Due to the ability of PCBs to induce cytochrome P-450 (Litterst et al., 1972) it has been suggested that the effects of PCBs on the reproductive system could be caused by an altered steroid hormone homeostasis (Nowicki \& Norman, 1972; Yoshihara et al., 1982). PCBs with a low chlorine content have a weak oestrogenic effect (Bitman \& Cecil, 1970). However, knowledge about endocrine changes in PCB-treated animals is limited (Jonsson et al., 1976; Örberg \& Ingvast, 1977; Aulerich et al., 1985). In a previous study (Lundkvist et al., 
1987) we showed that pregnant guinea-pigs that were treated with a PCB mixture had higher urinary concentrations of 11-ketotetranor prostaglandin F metabolites and oestrone sulphate during late gestation than did control animals. To continue this study, plasma concentrations of progesterone, 15-keto-13,14-dihydroprostaglandin F-2 $\alpha$ (15-ketodihydro-PGF-2 $\alpha$ ), oestrone sulphate and oestradiol-17 $\beta$ were determined under the same basic experimental conditions.

\section{Materials and Methods}

Animals. Guinea-pigs (Sahlens, Malmö, Sweden) of outbred Dunkin-Hartley stock were exposed to a 12-h light:12-h dark cycle at $23^{\circ} \mathrm{C}$. They were fed a standardized pellet food (Ewos, Södertälje, Sweden) containing $600 \mathrm{mg}$ ascorbic $\mathrm{acid} / \mathrm{kg}$ and tap water supplemented with ascorbic acid $(0.5 \mathrm{~g} / \mathrm{l})$. Nulliparous females were mated by placing 4 females together with 1 male. Mating was verified by the presence of spermatozoa in the vaginal smears (= Day 1 of gestation). The 15 experimental guinea-pigs each received by gavage the PCB mixture (Clophen A50: batch 949070 , Bayer AG, Leverkusen, FRG), $2 \cdot 2 \mathrm{mg} /$ day from Day 17 until Day 61 of gestation (Group CA). The 14 control guineapigs (Group $C$ ) were given the same daily volume of the vehicle $(0.2 \mathrm{ml}$ peanut oil per day). Body weight (means \pm s.d.) at the start of treatment was $697 \pm 47 \mathrm{~g}$ for Group CA and $704 \pm 86 \mathrm{~g}$ for Group C guinea-pigs. The gavage corresponds to a daily dose of $1.8-3.2 \mathrm{mg} / \mathrm{kg}$ body weight. Blood samples were collected on Days $17,26,36$, 46,56 and 66 of gestation. An anaesthesia of short duration was induced by injecting methohexital sodium (15-20 mg/ $\mathrm{kg}$ body wt; Brietal, Lilly) into one ear blood vessel; thereafter $5 \mathrm{ml}$ blood were collected by cardiac puncture into heparinized tubes. On Day 66 of gestation the dams were anaesthetized, laparotomized, the uterus exposed and the numbers of live and dead fetuses were determined. Gestational ages of the dead fetuses were estimated by measuring the fetal crown-rump length (Kaufmann \& Davidoff, 1977). Thereafter the placentas were bisected and a gross morphological investigation undertaken.

Assay of 15-keto-13,14-dihydro-PGF-2a. A 1-ml amount of plasma was extracted with 5 volumes of $n$-hexane (Merck, Darmstadt, FRG) for $15 \mathrm{~min}$. The supernatant was discarded, and then the plasma phase was acidified to a $\mathrm{pH}$ of 3.5-4.0 with $1 \mathrm{~N}-\mathrm{HCl}$ and extracted with 10 volumes of diethyl ether (Merck) for $30 \mathrm{~min}$. The ether phase was transferred to a glass vial and after spontaneous evaporation the residue was redissolved in $0.05 \mathrm{M}$-Tris buffer containing I mM-ethylene-diaminotetraacetate (EDTA) and $4.4 \mathrm{mg}$ albumin $/ \mathrm{ml}, \mathrm{pH} 8.0$. Two or more dilutions of the extract were analysed in duplicate for 15-keto-dihydro-PGF-2 $\alpha$ by radioimmunoassay as previously described (Granström \& Kindahl, 1982). The interassay coefficient of variation was $16 \%$ and the extraction recovery ranged from 58 to $62 \%$.

Progesterone assay. The antiserum was raised against $11 \alpha$-hydroxyprogesterone hemisuccinate bovine serum albumin (Bosu et al., 1976). Plasma samples were diluted in PBS buffer $(0.01 \mathrm{M}$-sodium phosphate, containing $0 \cdot 14 \mathrm{M}-\mathrm{NaCl}, 0 \cdot 1 \%$ gelatin and $0.01 \%$ thiomersal, $\mathrm{pH} 7 \cdot 0$ ). One volume of diluted plasma was mixed with one volume of $100 \%$ ethanol and left at room temperature for $15 \mathrm{~min}$. The samples were then extracted with 10 volumes of petroleum ether (b.p. $38-58^{\circ} \mathrm{C}$; Fisher Scientific Company, Fair Lawn, NJ, USA) for $15 \mathrm{~min}$. The petroleum ether phase was transferred to an assay tube and evaporated. To the residue was added $300 \mu \mathrm{l}$ PBS buffer, $100 \mu \mathrm{l}$ diluted antisreum (1:1500) and $100 \mu \mathrm{l}(0.2 \mathrm{pmol})$ [1,2,6,7- $\left.{ }^{3} \mathrm{H}(\mathrm{N})\right]$ progesterone (sp. act. $3.85 \mathrm{TBq} / \mathrm{mmol}$ : Amersham International plc, Amersham, UK). The tubes were mixed and incubated at $4^{\circ} \mathrm{C}$ overnight. Free and antibody-bound fractions were separated by adding $500 \mu \mathrm{l}$ dextran-coated charcoal $(0.5 \%$ Aktivekohle [Merck] and $0.1 \%$ dextran T70 [Pharmacia, Uppsala, Sweden]) in PBS without gelatin. After 10 min equilibration at $4^{\circ} \mathrm{C}$ the charcoal was separated by centrifugation at $1800 \mathrm{~g}$ for $15 \mathrm{~min}$. The supernatant was decanted into minivials, $3.5 \mathrm{ml}$ scintillation fluid (Miniria-20, Zinsser Analytic Ltd, Frankfurt, FRG) were added and radioactivity was counted in a liquid scintillation spectrometer. Stock solutions of progesterone (Sigma Reference Standards, Sigma, St Louis, MO, USA) were prepared in $100 \%$ ethanol and stored at $-20^{\circ} \mathrm{C}$. The standard curve range was $0.16-16$ pmol. The extraction recovery (mean \pm s.d.) of $\left[{ }^{3} \mathrm{H}\right]$ progesterone was $90 \cdot 7 \pm 2.7 \%$. The intra- and interassay coefficients of variation were $6 \%$ and $13 \%$, respectively.

Extraction procedure for oestrogens. One volume of plasma $(0.25$ or $0.5 \mathrm{ml})$ was extracted in duplicate with 10 volumes of freshly redistilled diethyl ether (Merck). The ether phase was transferred to and spontaneously evaporated in an assay tube, the residue was redissolved in $300 \mu \mathrm{l}$ PBS buffer and analysed for oestradiol-17ß. One volume of a salt solution, consisting of $10 \mathrm{ml}$ saturated $\mathrm{NaCl}$ and $800 \mu \mathrm{l} 0 \cdot 2 \mathrm{M}-\mathrm{NaH}_{2} \mathrm{PO}_{4}$, was then added to the remaining plasma phase. The plasma-salt solution was thoroughly mixed and left at room temperature for $30 \mathrm{~min}$. The mixture $(\sim \mathrm{pH} 7)$ was then extracted with $2 \times 5$ volumes of ethyl acetate (Merck) for $30 \mathrm{~min}$. The pooled ethyl acetate phase was evaporated under reduced pressure in a rotating centrifuge. The residue was redissolved in $300 \mu$ I PBS buffer containing $0 \cdot 1 \%$ albumin and analysed for oestrone sulphate. The recoveries (mean $\pm \mathrm{s.d}$.) of $\left[{ }^{3} \mathrm{H}\right]$ oestradiol or $\left[{ }^{3} \mathrm{H}\right]$ oestrone sulphate that had been equilibrated with plasma overnight were $83 \cdot 3 \pm 3 \cdot 5 \%(250 \mu \mathrm{l}$ plasma $)$ and $81 \cdot 6 \pm 3 \cdot 1 \%(500 \mu \mathrm{l}$ plasma $)$ for oestradiol, and $79 \cdot 2 \pm 2.0 \%(250 \mu \mathrm{l}$ plasma $)$ and $77 \cdot 7 \pm 0.8 \%(500 \mu \mathrm{l}$ plasma) for oestrone sulphate.

Assay of oestradiol-17\%. The oestradiol antiserum was raised in sheep against oestradiol-173-6-(O-carboxymethyl)-oxime-bovine serum albumin (Boilert et al., 1973). To each tube was added $100 \mu$ diluted antiserum (1: $600000)$ and $100 \mu \mathrm{l}(0 \cdot 1 \mathrm{pmol})\left[2,4,6,7-{ }^{3} \mathrm{H}\right]$ oestradiol-17 3 (sp. act. $3 \cdot 18 \mathrm{TBq} / \mathrm{mmol}$ : New England Nuclear, Boston, 
MA, USA) freshly prepared in PBS buffer. The tubes were incubated at $37^{\circ} \mathrm{C}$ for $30 \mathrm{~min}$ and $1 \mathrm{~h}$ on ice. Free and antibody-bound fractions were separated as described above for progesterone and the bound fraction was counted for radioactivity in a $10 \mathrm{ml}$ amount of Miniria-20. The range of the standard curve was 0.006-1.5 pmol. The intra- and interassay coefficients of variation were $6 \%$ and $17 \%$, respectively.

Assay of oestrone sulphate. The oestrone sulphate antiserum was raised against oestrone-3-glucuronide-bovine serum albumin. When $\left[{ }^{3} \mathrm{H}\right]$ oestrone sulphate was used as radioligand the cross-reactivity was $100 \%$ for oestrone,

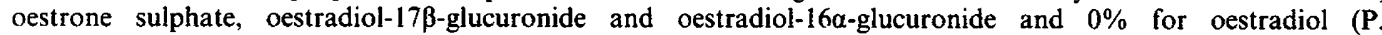
Samarajeewa, personal communication). Because of the considerable cross-reaction with several glucuronides the samples were extracted with ethyl acetate, in which glucuronides have low solubility. When samples were extracted, oestrone-3-glucuronide contributed to $\sim 4 \%$ of the amount measured (own measurement). Stock solutions of oestrone sulphate (Sigma) standards were stored in ammoniacal ethanol at $-20^{\circ} \mathrm{C}$. The range of the standard curve was 5-350 fmol/tube. To each standard tube, the same volume of 'blank plasma' (charcoal-stripped) was added and extracted in the same manner as the unknown samples. To the redissolved extract $100 \mu \mathrm{l}$ antiserum $(1: 20000)$ and $100 \mu \mathrm{l}(0 \cdot 15 \mathrm{pmol})\left[{ }^{3} \mathrm{H}\right]$ oestrone sulphate $\left(\left[6,7-{ }^{3} \mathrm{H}(\mathrm{n})\right]\right.$ oestrone sulphate ammonium salt, sp. act. $1.48 \mathrm{TBq} / \mathrm{mmol}$ : New England Nuclear), freshly prepared in PBS- $0.1 \%$ albumin, were added. The tubes were incubated at $37^{\circ} \mathrm{C}$ for $30 \mathrm{~min}$ and overnight at $4^{\circ} \mathrm{C}$. Free and antibody-bound fractions were separated as described above for progesterone and the bound fraction was counted for radioactivity in a 10-ml amount of Miniria-20. The intra- and interassay coefficients of variation were $7 \%$ and $18 \%$, respectively.

Statistical analyses. The statistical evaluation of litter size, number of live and dead fetuses, sex ratios, placental weight, fetal weight and length was made by Student's $t$ test (two-tailed) or the $\chi^{2}$ test for heterogeneity (two-tailed).

Plasma samples of the same gestational ages were assayed on the same occasion for either of the hormones. Blanks have been deducted and procedural losses compensated for in the data presented. Differences between plasma values of each of the hormones were analysed by Student's $t$ test, which was used in a modified form if the variances were unequal by the variance F-ratio test (Bailey, 1979). The blank values (mean \pm s.d.) were $6.1 \pm 1.4 \mathrm{pg} / 250 \mu 1$ and $7 \cdot 8 \pm 1 \cdot 6 / 500 \mu \mathrm{l}$ plasma and so the oestradiol-17ß determinations before Day 45 of gestation were close to or below the limit of detection and were subsequently omitted from the statistical evaluation.

\section{Results}

\section{Clinical findings}

The guinea-pigs maintained gestation until autopsy on Day 66, with the exception of one which delivered on Day 65. The litter size, numbers of live and dead fetuses, fetal and placental weight and sex ratio of the living fetuses are shown in Table 1 . There were no significant differences in placental or fetal weight, or body length of living fetuses between Groups CA and C. The estimated gestational ages of the dead fetuses, mainly based on crown-rump length measurements, are shown in Table 2 . Since it is likely that a retardation in growth rate precedes the fetal death and that the fetuses shrink during the resorption process, this figure should represent the earliest time of fetal death. In Group CA, 2 females had no living fetuses and 4 females had fully viable litters. Only one very early resorption occurred in Group $\mathrm{C}$ animals. The widening of the pubic symphysis tended to start earlier in Group $\mathrm{CA}$ and for some $(\mathrm{N}=4)$ the vaginal membrane was perforated and the vagina was bleeding. Resorptions were not markedly more abundant in any particular part of the uterus. The corpora lutea were still visible in both treatment groups, although a reliable assessment of the weight could not be done at the time. The placentas from dead fetuses were not fully detached: they were either mummified or full-term placentas with widespread infarctions and little or no circulation.

\section{Endocrine changes}

The plasma concentrations of 15-keto-dihydro-PGF- $2 \alpha$, progesterone, oestrone sulphate and oestradiol-17 $\beta$ throughout gestation are shown in Fig. 1. In Group CA oestradiol-17 $\beta$ and oestrone sulphate concentrations were elevated on Day 56 , and were positively correlated with each other on Days $56(P \leqslant 0.01)$ and $66(P \leqslant 0.001)$ of gestation. Concentrations of plasma 15-keto-dihydroPGF- $2 \alpha$ were significantly higher in Group CA than in Group C animals on Days 46 and 56. The variation was large, especially on Day 66 . There were no significant differences in plasma progesterone concentrations between the two treatment groups. Towards the end of gestation, when fetal 
Table 1. Number of dead fetuses, sex ratio, fetal length, fetal and placental weight on Day 66 of gestation in guinea-pigs treated with vehicle only (Group C) or Clophen A50 (Group CA)

\begin{tabular}{|c|c|c|}
\hline & $\begin{array}{l}\text { Group C } \\
\text { (Control) }\end{array}$ & $\begin{array}{c}\text { Group CA } \\
(\text { Clophen A50) } \dagger\end{array}$ \\
\hline No. of females & 14 & 15 \\
\hline No. of implantation sites & 47 & 54 \\
\hline Litter size (mean \pm s.d.) & $3.4 \pm 1 \cdot 0$ & $3.6 \pm 0.9$ \\
\hline Frequency of dead fetuses (\%) & $2 \cdot 1$ & $42 \cdot 6^{*}$ \\
\hline Frequency of mummified fetuses $(\%) \uparrow$ & $2 \cdot 1$ & $25 \cdot 3^{*}$ \\
\hline Frequency of males/females (\%) $\ddagger$ T & $61 / 40$ & $48 / 52$ \\
\hline $\begin{array}{l}\text { Fetal weight (mean } \pm \text { s.d.; g) }+\S \\
\quad \text { Males } \\
\text { Females }\end{array}$ & $\begin{array}{l}91 \cdot 4 \pm 14 \cdot 4 \\
87 \cdot 3 \pm 18 \cdot 0\end{array}$ & $\begin{array}{l}86 \cdot 4 \pm 14 \cdot 6 \\
79 \cdot 3 \pm 20 \cdot 4\end{array}$ \\
\hline $\begin{array}{l}\text { Fetal length (mean } \pm \text { s.d.; mm) } \ddagger \S \\
\text { Males } \\
\text { Females }\end{array}$ & $\begin{array}{l}118 \pm 14 \\
117 \pm 14\end{array}$ & $\begin{array}{l}118 \pm 8 \\
116 \pm 11\end{array}$ \\
\hline $\begin{array}{l}\text { Placental weight (mean } \pm \text { s.d.; g) } \$ \S \\
\text { Males } \\
\text { Females }\end{array}$ & $\begin{array}{l}4.1 \pm 0.8 \\
3.7 \pm 0.8\end{array}$ & $\begin{array}{l}3.8 \pm 0.8 \\
3.8 \pm 0.8\end{array}$ \\
\hline
\end{tabular}

$†$ Total dose, $100 \mathrm{mg}$ during Days 17-61 of gestation.

$\ddagger$ Refers only to living fetuses.

$\S$ Student's $t$ test (two-tailed).

$\uparrow \chi^{2}$ test (two-tailed).

${ }^{*} P \leq 0.001$, compared with control.

Table 2. Gestational ages of dead fetuses from Clophen A50-treated guinea-pigs, estimated by crown-rump length measurements in normally developed fetuses

\begin{tabular}{lcc}
\hline $\begin{array}{l}\text { Crown-rump } \\
\text { length (mm) }\end{array}$ & Days & No. of fetuses \\
\hline$\approx 10$ & $15-19$ & 3 \\
$50-79$ & $40-49$ & 10 \\
$80-99$ & $50-59$ & 8 \\
$\approx 110$ & $60-65$ & 2 \\
\hline
\end{tabular}

death was extensive, this high mortality was not reflected in the progesterone concentrations: the 2 females with no viable fetuses maintained high progesterone concentrations until the end of the experiment (Fig. 2).

\section{Discussion}

Guinea-pigs treated with Clophen A50 had higher plasma concentrations of 15-keto-dihydroPGF- $2 \alpha$ and oestrone sulphate during late gestation compared to controls. The fact that both hormones increased about Day 56 of gestation indicates that there might be a causal relationship.

That fetal death was connected with increased concentrations of oestrone sulphate and unaltered plasma progesterone concentrations was unexpected. Determinations of oestrone sulphate in plasma, urine or milk have been used to verify pregnancy or fetal viability in domestic animals. Generally, delivery, fetal death or abortion is preceded or followed by a rapid fall in maternal 

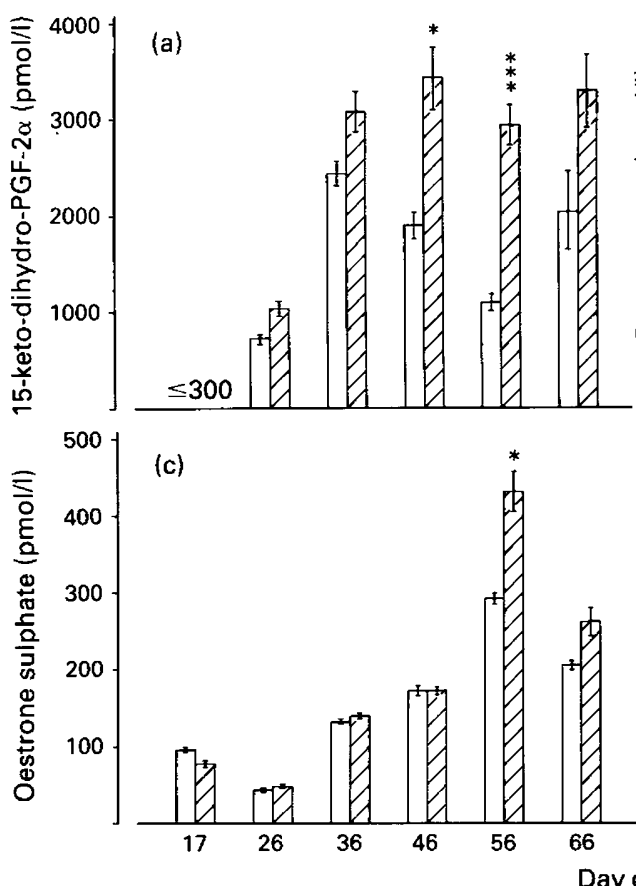

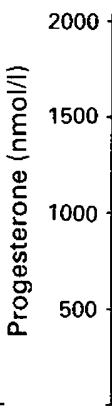

(b)

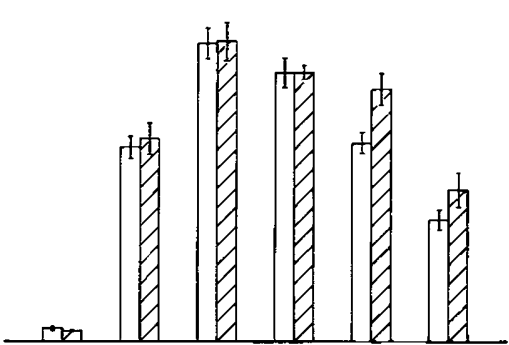

(d)

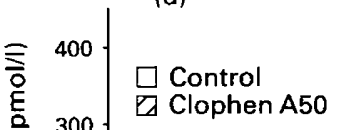

$\square$ Clophen A50

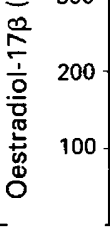

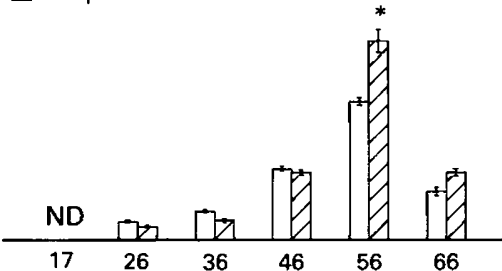

Fig. 1. Plasma concentrations (mean \pm s.e.m.) of (a) 15-keto-dihydro-PGF-2 $\alpha$, (b) progesterone, (c) oestrone sulphate and (d) oestradiol-17 $\beta$ in guinea-pigs treated with Clophen A50 (Group CA) (total dose $100 \mathrm{mg}$ during Days 17-61 of gestation) and with vehicle only (Group C). ${ }^{*} P \leq 0.05,{ }^{* * *} P \leq 0.001$ compared with Group $\mathrm{C}$ values $(t$ test $)$; n.d., not detected.

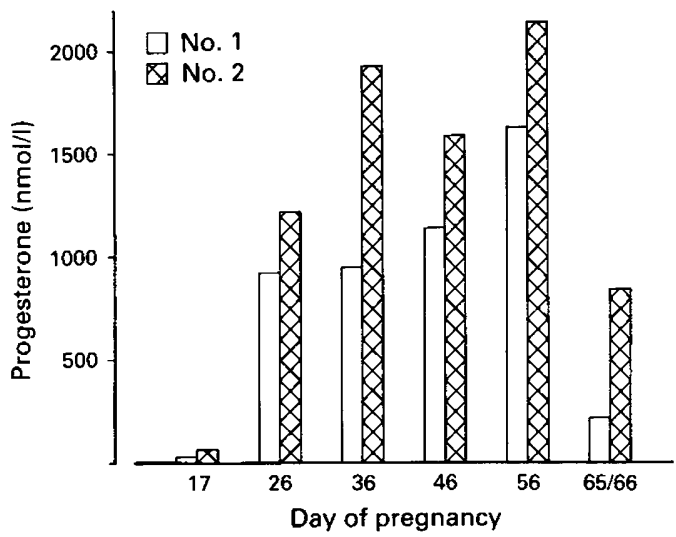

Fig. 2. Plasma concentrations of progesterone in 2 guinea-pigs treated with Clophen A50 (total dose $100 \mathrm{mg}$ during Days 17-61 of gestation) with no surviving offspring. Guinea-pig 1 delivered 3 dead fetuses on Day 65 of gestation: 2 died between Days 40 and 50 while the 3rd died between Days 55 and 60. Guinea-pig 2 had 4 dead fetuses of estimated gestational age 40-55 days.

oestrone sulphate concentrations (Robertson \& King, 1974; Madej et al., 1987; Mohamed et al., 1987; Kasman et al., 1988). It is therefore strongly suggested that the products of conception produce or control the production of oestrone sulphate. 
The guinea-pig lacks a plasma protein that binds oestrogens in a specific way, and so sulphoconjugation could constitute a mechanism for regulating the availability of unconjugated oestrogens (Adessi et al., 1978). Because the chorionic blood supply is of fetal origin it has been suggested that oestrone sulphotransferase in chorion and uterus may be controlled by the fetus and that an increased sulphoconjugation of oestrogens could be a factor in initiation of parturition (Freeman et al., 1983). The increase in oestrone sulphate in urine and plasma in our previous (Lundkvist et al., 1987) and present study is in accordance with oestrone sulphotransferase activity present in the chorion and uterus, which peaked around Days 47 and 56 of gestation (Freeman et al., 1983). There is some evidence that the production of oestrone sulphate is controlled by progesterone (Freeman \& Hobkirk, 1978; Pack et al., 1979; Clarke et al., 1982).

The increased sulphoconjugation in PCB-treated females could be a protective mechanism to maintain gestation. On the other hand, steroid sulphates have been reported to stimulate human phospholipase $\mathrm{A}_{2}$ activity, the rate-limiting step in PG synthesis, while the corresponding unconjugated steroids are inefficient in this respect (Saitoh et al., 1984). In guinea-pigs the main site of in-vivo uptake of arachidonic acid shifts from the fetal membranes to the uterus between Days 40 and 60 of gestation (Mucha et al., 1983). Therefore, the fetal membranes have been suggested to be a depot of arachidonic acid that is redistributed at the end of gestation to serve as precursor for the uterine synthesis of PGFs (Mucha et al., 1983). Our previous study showed that around Day 59 of gestation there is frequently a clear peak of metabolite of PGF- $2 \alpha$ in guinea-pig urine (Lundkvist et al., 1987). This release of PGF-2 $\alpha$ might be related to the increasing plasma oestrogen concentrations around Day 56 of gestation.

The temporal relationship between the increase in 15-keto-dihydro-PGF-2 $\alpha$ levels in the PCBtreated guinea-pigs and fetal death is difficult to assess. Support for the concept that prostaglandins could be involved in the toxic effects of PCBs has been provided by studies on chick embryos, in which PCBs were injected into hens' eggs alone or in combination with benoxaprofen (prostaglandin synthesis inhibitor). The addition of benoxaprofen decreased embryonic mortality, but had no influence on the induction of P-448 (Rifkind \& Muschick, 1983). Tissues from PCB-exposed embryos also showed an increased synthesis of prostaglandins (Rifkind et al., 1984).

It is not known whether the first signs of a toxic response to PCB treatment in guinea-pigs appears in the fetus or in the mother. At autopsy 2 living fetuses (from different litters) were very small ( $\sim 40 \mathrm{~g}$ and $\sim 95 \mathrm{~mm}$ ) and had pale, infarcted placentas. A third dam was examined on Day 49 of gestation because of vaginal bleeding. One uterine horn contained a resorbed fetus while the other contained 2 living fetuses of normal weight, but there were white, infarcted areas in the basal part of the main placenta. Normally, infarctions occur during the very last days of gestation, usually together with the widening of the pubic symphysis (Kaufmann \& Davidoff, 1977). According to Kaufmann (1975) the formation of an infarction takes about 10 days. Therefore, we suggest that in this case the mode of action by which prostaglandins could threaten fetal survival is via their oxytocic properties in the uterus, but it should be stressed that the increased PGF metabolite levels could have been caused by the dead fetuses since distortion of tissue stimulates prostaglandin release. A histological study to establish when the observed degenerative changes starts would be useful for a better understanding of the endocrine data and the cause of fetal death.

Despite the fetal loss in the guinea-pigs treated with Clophen A50, progesterone values remained high throughout gestation. This is surprising since during the last third of gestation most of the circulating progesterone is of placental origin (Heap \& Illingworth, 1974; Tam, 1977). Owing to the low sampling frequency there could have been an unnoticed transient fall in plasma progesterone that was counteracted via compensatory mechanisms. Although it has been reported that in mice pretreatment with PCB augments LH-induced progesterone of corpora lutea cultured in vitro (Fuller et al., 1980), it is unlikely that the corpus luteum could be stimulated to such an extent at the end of gestation. Neither were there any signs of placental hyperfunction, i.e. placental weights were not increased. The most likely explanation is that, despite fetal death, progesterone binding globulin (PBG) is still present in maternal plasma and thereby protects progesterone from 
degradation. These results contradict the supposition that a viable conceptus should be the stimulus for production of PBG (Illingworth et al., 1970; Milgrom et al., 1973; Heap \& Illingworth, 1974; Evans et al., 1982), and determinations of plasma progesterone concentrations in the guinea-pig are clearly unreliable indicators of fetal viability. The present results provide no support for the hypothesis that an enzyme-induced decrease in plasma progesterone concentrations is the main cause of the fetal death observed in PCB-treated guinea-pigs.

We thank Dr P. Samarjeewa (Department of Biochemistry, University College London, London, UK) for the oestrone-glucuronide antiserum; and Professor L.-E. Edqvist (Department of Clinical Chemistry, Swedish University of Agricultural Sciences, Uppsala) for the gift of progesterone and oestradiol antisera. This work was supported by grants from the Swedish Council for Planning and Coordination of Research, the Swedish Council for Forestry and Agricultural Research, and the Lars Hiertas Memorial Fund.

\section{References}

Adessi, G.L., Goutte-Coussieu, C., Nhuan, T.Q., Eichenberger, D. \& Jayle, M.F. (1978) Conversion, in vitro, of $\left(7 n-{ }^{3} \mathrm{H}\right)$ testosterone to estrone and estradiol $17-\beta$ and their 3 -sulfate conjugate by guinea pig placenta. Steroids 32, 295-306.

Aulerich, R.J., Bursian, S.J., Breslin, W.J., Olson, B.A. \& Ringer, R.K. (1985) Toxicological manifestations of $2,4,5,2^{\prime}, 4^{\prime}, 5^{\prime}-, 2,3,6,-2^{\prime}, 3^{\prime}, 6^{\prime}-$, and $3,4,5,3^{\prime}, 4^{\prime}, 5^{\prime}$-hexachlorobiphenyl and Aroclor 1254 in mink. J. Toxicol. Environm. Health 15, 63-79.

Bailey, N.T.J. (1979) Statistical Methods in Biology. Hodder and Stoughton, London, UK.

Barsotti, D.A., Marlar, R.J. \& Allen, J.R. (1976) Reproductive dysfunction in rhesus monkeys exposed to low levels of polychlorinated biphenyls (Aroclor 1248). Fd Cosmet. Toxicol. 14, 99-103.

Bitman, J. \& Cecil, H.C. (1970) Estrogenic activity of DDT and polychlorinated biphenyls. J. agr. Food Chem. 18, 1108-1112.

Boilert, B., Edqvist, L.-E., Johansson, E.D.B., Lindberg, P. \& Martinsson, K. (1973) The influence of conjugated estrogens in radioimmunoassays using different antibodies against estradiol-17 $\beta$. Steroids 22, 891-895.

Bosu, W.T.K., Edqvist, L.-E., Lindberg, P., Martinsson, K. \& Johansson, E.D.B. (1976) The effect of various dosages of lynesterol on the plasma level of oestrogens and progesterone during the menstrual cycle in the rhesus monkey. Contraception 13, 677-684.

Brandt, I., Darnerud, P.O., Bergman, §. \& Larsson, Y. (1982) Metabolism of 2,4',5-trichlorobiphenyl: enrichment of hydroxylated and methyl sulphone metabolites in uterine luminal fluid of pregnant mice. Chem.-Biol. Interactions 40, 4546.

Brezner, E., Terkel, J. \& Perry, A.S. (1984) The effect of Aroclor 1254 (PCB) on the physiology and reproduction in the female rat-I. Comp. Biochem. Physiol. 77C, 65-70.

Brunström, B., Kihlström, I. \& Lundkvist, U. (1982) Studies of foetal death and foetal weight in guinea pigs fed polychlorinated biphenyls (PCB). Acta pharmacol. toxicol. 50, $100-103$.

Clarke, C.L., Adams, J.B. \& Wren, B.G. (1982) Induction of estrogen sulfotransferase in the human endo- metrium by progesterone in organ culture. J. clin. Endocr. Metabol. 55, 70-75.

Darnerud, P.O., Brandt, I., Klasson-Wehler, E., Bergman, A., d'Argy, L., Dencker, L. \& Sperber, G. O. (1986) $3,3^{\prime}, 4,4^{\prime}$-tetrachloro- $/{ }^{14} \mathrm{C} /$ biphenyl in pregnant mice: enrichment of phenol and methylsulphonyl metabolites in late gestational fetuses. Xenobiotica 16, 295-306.

Evans, J.J., Sin, I.L. \& White, F.J. (1982) Progesterone binding globulin and progesterone in guinea-pigs after ovariectomy, abortion and parturition. $J$. Steroid Biochem. 16, 171-173.

Freeman, D.J. \& Hobkirk, R. (1978) The metabolism of oestradiol-17 $\beta$ by the pregnant guinea pig uterus in vitro. Biochim. Biophys. Acta 540, 478-483.

Freeman, D.J., Saidi, F. \& Hobkirk, R. (1983) Estrogen sulfotransferase activity in guinea pig uterus and chorion. J. Steroid Biochem. 18, 23-27.

Fuller, G.B. \& Hobson, W.C. (1986) Effects of PCBs on reproduction in mammals. In PCBs and the Environment, vol. II, pp. 101-127, Ed. J.S. Wald. CRC Press, Inc., Boca Raton.

Fuller, G.B., Knauf, V., Mueller, W. \& Hobson, W.C. (1980) PCB augments LH-induced progesterone synthesis. Bull. Environm. Contam. Toxicol. 25, 65-68.

Granström, E. \& Kindahl, H. (1982) Radioimmunoassay of the major plasma metabolite of PGF-2 $\alpha, 15$-keto13,14-dihydro-PGF-2a. Methods Enzymol. 86, $302-839$.

Heap, R. B. \& Illingworth, D. V. (1974) The maintenance of gestation in the guinea-pig and other hystricomorph rodents: changes in the dynamics of progesterone metabolism and the occurrence of progesterone-binding globulin (PBG). Symp. zool. Soc. Lond. 34, 385-415.

Higuchi, K. (1976) PCB Poisoning and Polution. Academic Press, New York.

Hutzinger, O., Safe, S. \& Zitko, V. (1974) The Chemistry of PCBs. CRC Press, Cleveland.

Illingworth, D.V., Heap, R.B. \& Perry, J.S. (1970) Changes in the metabolic clearance rate of progesterone in the guinea pig. J. Endocr. 48, 409-417.

Jensen, S. (1966) Report on a new chemical hazard. New Sci. 32, 612. 
Jensen, S. \& Sundström, G. (1974) Structures and levels of most chlorobiphenyls in two technical PCB products and in human adipose tissue. Ambio 3, 71-76.

Jonsson, H.T., Keil, J.E., Gaddy, R.G., Loadholt, C.B., Hennigar, G.R. \& Walker, E.M. (1976) Prolonged ingestion of commercial DDT and PCB; effects on progesterone levels and reproduction in the mature female rat. Archs Environ. Contam. Toxicol. 3, $479-490$.

Kasman, L.H., Hughes, J.P., Stabenfeldt, G.H., Starr, M.D. \& Lasley, B.L. (1988) Estrone sulfate concentrations as an indicator of fetal demise in horses. $\mathrm{Am}$. J. vet. Res. 49, $184-187$.

Kaufmann, P. (1975) Experiments on infarct genesis caused by blockage of carbohydrate metabolism in guinea pig placentae. Virchows Arch. path. Anat. 368 , 11-21.

Kaufmann, P. \& Davidoff, M. (1977) The Guinea-Pig Placenta. In Advances in Anatomy, Embryology and Cell Biology, vol. 53, 1-91. Springer-Verlag.

Linder, R.E., Gaines, T.B. \& Kimbrough, R.D. (1974) The effect of polychlorinated biphenyls on rat reproduction. Fd Cosmet. Toxicol. 12, 63-77.

Litterst, C.L., Farber, T.M., Baker, A.M. \& Van Loon, E.J. (1972) Effect of polychlorinated biphenyls on hepatic microsomal enzymes in the rat. Toxicol. Appl. Pharmacol. 23, 112-122.

Lundkvist, U., Kindahl, H. \& Madej, A. (1987) Urinary levels of estrone sulfate and 11-ketotetranor prostaglandin $\mathrm{F}$ metabolite in pregnant guinea pigs given Clophen A50 (polychlorinated biphenyls). Biol. Reprod. 36, 109-116.

Madej, A., Kindahl, H., Nydahl, C., Edqvist, L.-E. \& Stewart, R.D. (1987) Hormonal changes associated with induced late abortions in the mare. J. Reprod. Fert., Suppl. 35, 479. 484.

Masuda, Y., Kagawa, R., Tokudome, S. \& Kuratsune, M. (1978) Transfer of polychlorinated biphenyls to foetuses and offspring of mice. Fd Cosmet. Toxicol. 16, 33-37.

Masuda, Y., Kagawa, R., Kuroki, H., Tokudome, S. \& Kuratsune, M. (1979) Transfer of various polychlorinated biphenyls to the fetuses and offspring of mice. Fd Cosmet. Toxicol. 17, 623-627.

McNulty, W.P. (1985) Toxicity and fetotoxicity of TCDD, TCDF and PCB isomers in rhesus macaques (Macaca mulatta). Environ. Health Perspec. 60, 77-88.

Milgrom, E., Allouch, P., Atger, M. \& Baulieu, E.E. (1973) Progesterone binding plasma protein of pregnant guinea-pig. J. biol. Chem. 248, 1106-1114.

Mohamed, A.R., Noakes, D.E., Booth, J.M. \& Chaplin, V. (1987) Plasma oestrone sulphate and progesterone concentrations in cows and ewes associated with fetal death and abortion. Br. vet. J. 143, 238-245.

Mucha, I., Tanács, B. \& Bagdány, S. (1983) Arachidonic acid metabolism in reproductive tissues of pregnant guinea pig under in vivo circumstances. Prostaglandins, Leuk. Med. 12, 207-216.

Nowicki, H.G. \& Norman, A.W. (1972) Enhanced hepatic metabolism of testosterone, 4-androstene-3,17dione, and estradiol- $I 7 \beta$ in chickens pretreated with DDT or PCB. Steroids 19, 85-99.

Örberg, J. \& Ingvast, C. (1977) Effects of pure chlorobiphenyls $\left(2,4^{\prime}, 5\right.$-trichlorobiphenyl and $2,2^{\prime}, 4,4^{\prime}, 5,5^{\prime}$ hexachlorobiphenyl) on the disappearance of ${ }^{14} \mathrm{C}$ from the blood plasma after intravenous injection of 4- ${ }^{14} \mathrm{C}$-progesterone and on the hepatic drug metabolizing system in the female rat. Acta pharmacol. toxicol. 41, 11-17.

Pack, B.A., Brooks, C.L., Dukelow, W.R. \& Brooks, C.S. (1979) The metabolism and nuclear migration of estrogen in porcine uterus throughout the implantation process. Biol. Reprod. 20, 545-551.

Rifkind, A.B. \& Muschick, H. (1983) Benoxaprofen suppression of polychlorinated biphenyl toxicity without alteration of mixed function oxidase function. Nature, Lond. 303, 524-526.

Rifkind, A.B., Hattori, Y., Levi, R., Hughes, M.J., Quilley, C. \& Alonso, D. (1984) The chick embryo as a model for PCB and dioxin toxicity: evidence of cardiotoxicity and increased prostaglandin synthesis. In Biological Mechanisms of Dioxin Action, pp. 255-266. Eds A. Poland \& R. Kimbrough. Cold Spring Harbor Laboratory.

Ring, B.J., Seitz, K.R. \& Vodicnik, M.J. (1988) Transfer of $2,4,5,2^{\prime}, 4^{\prime}, 5^{\prime}$-hexachlorobiphenyl across the in situ perfused guinea pig placenta. Toxicol. appl. Pharmacol. 96, 7-13.

Robertson, H.A. \& King, G.J. (1974) Plasma concentrations of progesterone, oestradiol-17 $\beta$ and of oestrone sulphate in the pig at implantation, during pregnancy and parturition. J. Reprod. Fert. 40, $133-141$.

Safe, S. (1984) Polychlorinated biphenyls (PCBs) and polybrominated biphenyls (PBBs): biochemistry, toxicology, and mechanism of action. CRC Crit. Rev. Toxicol. 13, 319-395.

Saitoh, H., Hiato, K., Tahara, R., Ogawa, K., Noguchi, Y., Yanaihara, T. \& Nakayama, T. (1984) Enhancement of human amniotic phospholipase $\mathrm{A}_{2}$ activity by steroid-sulphate derived from the foeto-placental unit. Acta endocr., Copenh. 107, 420-424.

Shain, W., Overmann, S., Wilson, L., Kostas, J. \& Bush, B. (1986) A congener analysis of polychlorinated biphenyls accumulating in rat pups after perinatal exposure. Archs Environ. Contam. Toxicol. 15, 687-707.

Sparling, J. \& Safe, S. (1980) The effect of ortho chloro substituents on the retention of PCB isomers in rat, rabbit, japanese quail, guinea pig and trout. Toxicol. Letters 7, 23-28.

Tam, W.H. (1977) The in vitro steroid synthesis by the placenta of the guinea pig and progesterone concentrations in systemic and uterine plasma. $J$. Endocr. 73, $483-489$.

Villeneuve, D.C., Grant, D.L., Khera, K., Clegg, D.J., Baer, H. \& Phillips, W.E. (1971) The fetotoxicity of a polychlorinated biphenyl mixture (Aroclor 1254) in the rabbit and in the rat. Environ. Physiol. 1, 67-71.

Vodicnik, M.J. \& Leech, J.J. (1980) The transfer of $2,4,5,2^{\prime}, 4^{\prime}, 5^{\prime}$-hexa-chlorobiphenyl to fetuses and nursing offspring. Toxicol. appl. Pharmacol. 54, 293-300.

Yoshihara, S., Nagata, K., Wada, I., Yoshimura, H., Kuroki, H. \& Masuda, Y. (1982) A unique change of steroid metabolism in rat liver microsomes induced with highly toxic polychlorinated biphenyl (PCB) and polychlorinated dibenzofuranes (PCDF). $J$. Pharmac. Dynam. 5, 994-1004. 